\title{
NOVITATES GABONENSES 69. A NEW ENDEMIC SPECIES OF AND A NEW COMBINATION IN CAMPYLOSPERMUM (OCHNACEAE)
}

\author{
P. BISSIENGOU ${ }^{1} \&$ M.S.M. SOSEF 2
}

\begin{abstract}
SUMMARY
A new species of Campylospermum endemic to the Crystal Mountains, Gabon, and belonging to sect. Notocampylum is described. Besides that, a West-Central African species of Ouratea, nowadays a strictly South American genus, is transferred to Campylospermum and the necessary new combination made.
\end{abstract}

Key words: Ochnaceae, Campylospermum, Ouratea, Africa, Gabon, Crystal Mountains, endemism, taxonomy.

\section{INTRODUCTION}

While studying the Ochnaceae material kept at the Wageningen branch of the National Herbarium of the Netherlands (WAG) and the National Herbarium of Gabon (LBV) we came across several specimens of an unknown species of Campylospermum Tiegh., all from the Crystal Mountains. They did not fit the description of any species known from the work of Farron $(1965,1985)$ and Bamps \& Farron $(1967)$, nor could we match it with any of the species treated in the Flora of West Tropical Africa (Hutchinson \& Dalziel 1954) or in the Checklist of Gabonese vascular plants (Sosef et al. 2006). We then concluded that the material must represent a new species.

The Crystal Mountains are one of Gabon's regions with an exceptionally high botanical diversity (Breteler 1990, Wilks 1990, De Wilde 1994) and recognized as a former glacial rain forest refuge area (Sosef 1994). At least 29 plant species are already known to be endemic to the Gabonese part of the Crystal Mountains (figure based on the Plants of Gabon database available at http://herbaria.plants.ox.ac.uk/bol5/home/), among which 4 species of Begonia, 4 orchids and 7 Rubiaceae. The Crystal Mountains continue north into Equatorial Guinea and when that part is added, the number of species endemic to this mountain range will undoubtedly increase. The new species thus brings the number of Gabonese Crystal Mountain plant endemics to 30 confirming the unique character of the local rain forest vegetation. Parts of the Crystal Mountains have been declared the status of national park, but further attention to its conservation is needed, especially regarding the threat of open mining activities (http://www.wcs.org/ international/Africa/gabon/crystalmountains).

1) Herbier National du Gabon, IPHAMETRA-CENAREST, B.P. 1156, Libreville, Gabon.

2) Nationaal Herbarium Nederland, Wageningen branch, Biosystematics group, Wageningen University, Generaal Foulkesweg 37, 6703 BL Wageningen, The Netherlands. 


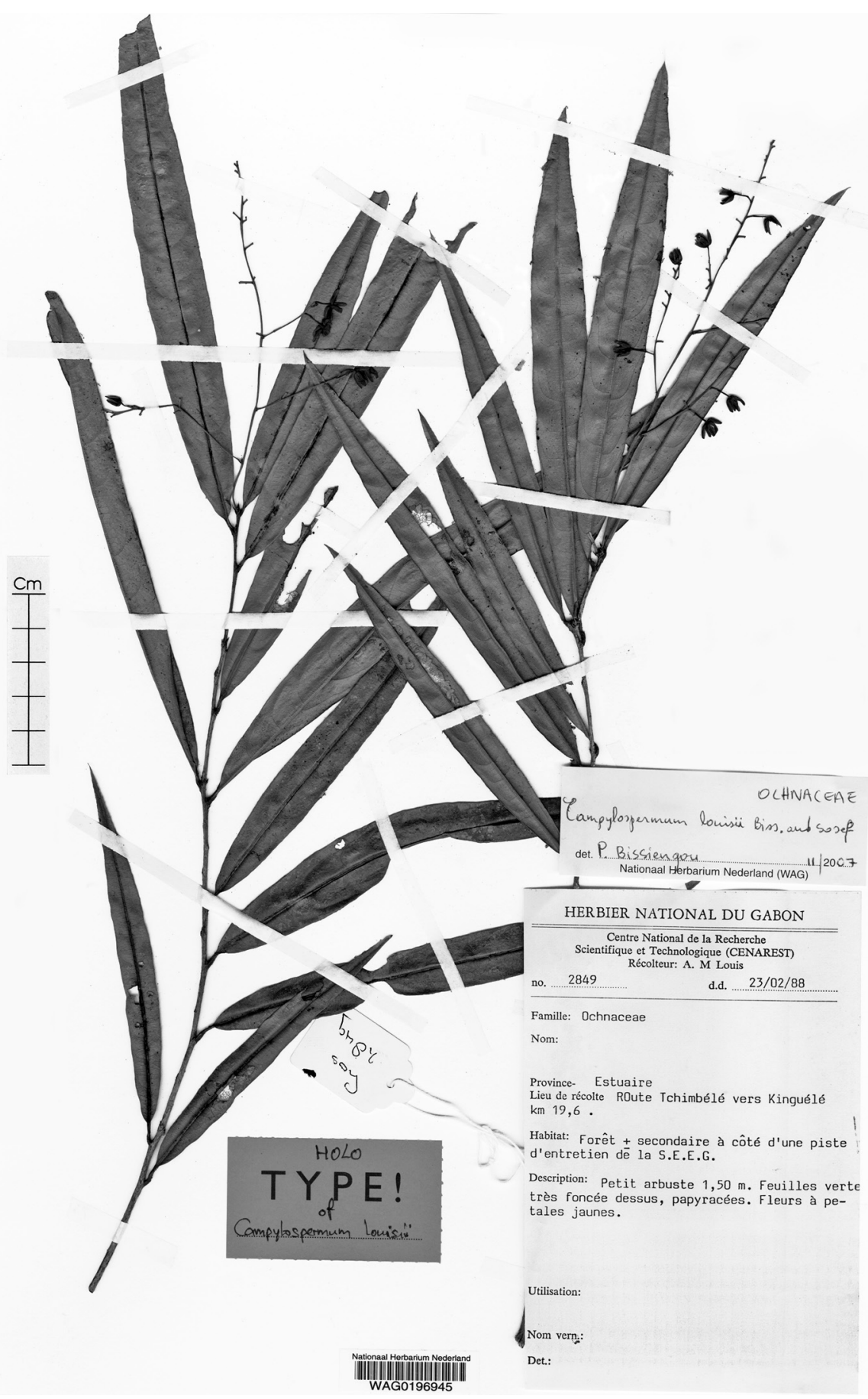

Fig. 1. Holotype specimen of Campylospermum louisii Bissiengou \& Sosef, Louis 2849, at WAG. 
The species is readily distinguished, even at first glance, from any other known Campylospermum species by its long and ensiform leaves with (12-)15-20 lateral veins on either side. Other diagnostic features are its entire or minutely and distantly serrate leaf margin, the 1.5-5 mm long petiole and the terminal inflorescence (Fig. 1). It may look similar to narrow-leaved specimens of Campylospermum laeve (De Wild. \& T.Durand) Farron. However, the leaf of $C$. laeve has a densely serrulate and thickened margin, only up to 12 lateral veins on either side, and a 5-6 mm long petiole. The lateral veins of $C$. laeve are less distinct than those of the new species. Its inflorescence is overtopping the subtending leaves while in the new species the inflorescence is shorter than the subtending leaves. The new species seems to be smaller in size (1-2 m high) than $C$. laeve ( $2-5 \mathrm{~m}$, rarely up to $12 \mathrm{~m}$ high). Finally, the incumbent cotyledons of more or less equal size and the terminal inflorescence render the new species a member of the sect. Notocampylum (Tiegh.) Farron, rather than of sect. Monelasmum (Tiegh.) Farron to which C. laeve belongs (Farron 1968).

\section{DESCRIPTION}

Campylospermum louisii Bissiengou \& Sosef, spec. nov. - Fig. 1; Map 1

Haec species propria foliis longis $(9.5-28 \mathrm{~cm})$ ensiformis margine integro vel dissitiserrulato, inflorescentia terminali breviore quam foliis subtentis et cotyledonibus amplitudine plus minusve aequalibus incumbentibusque. - Typus: Louis 2849 (holo WAG!; iso LBV!, MO), Gabon, Estuaire Province, Route Tchimbélé vers Kinguélé à $19.6 \mathrm{Km}$, N 0.3400', E 10²19', 23 Feb. 1988.

Shrub or small tree of up to $2 \mathrm{~m}$ high. Leaves: stipules semi-caducous, narrowly triangular, c. $3 \mathrm{~mm}$ long; petiole 1.5-5 mm long; leaf blade thick papery, ensiform, $9.5-28$ by $1.3-2.4 \mathrm{~cm}$, cuneate to attenuate at base, apex long tapering or sometimes mucronulate at the very tip, margin entire to serrulate with distant reduced teeth, upper surface glossy dark green, lower surface greenish; venation distinct on both surfaces, midrib sunken on the upper surface, prominent on the lower, main lateral veins (12-) 15-20 on either side, curved upwards becoming tangent to the margin; intermediate lateral veins less prominent, more or less at right angles to the midrib, not reaching the margin; tertiary veins parallel to reticulate. Inflorescence terminal, the central axis (4-)7-18 cm long with 1-4 racemes branching off and a few persistent bracts at its base; cymules 1-3-flowered. Flowers (no complete flowers observed): pedicel 3-10 $\mathrm{mm}$ long, orange, articulating at $1-5 \mathrm{~mm}$ from the base; sepals ovate, $3-7$ by $1-2.5$ $\mathrm{mm}$, enlarged and dark red in fruit; petals yellow; stamens 10. Fruit: receptacle accrescent, \pm globose, red; drupelets only 2 to 3 well developed per receptacle, broadly ellipsoid, 5-9 by 4-7 $\mathrm{mm}$, green turning pink (presumably immature) and finally black; cotyledons more or less equal, incumbent.

Distribution - Gabon, endemic to the Crystal Mountains.

Ecology - Growing in primary and secondary forest at around $500 \mathrm{~m}$ altitude.

Vernacular name - Alen-opwbon (Fang).

Eponymy - The species is dedicated to Ard Louis, former Head of the Herbier National du Gabon. He has played a crucial role in the creation of this research facility, collected two of the four presently known specimens of the new species and has been instrumental in promoting the botanical inventory of Gabon. 


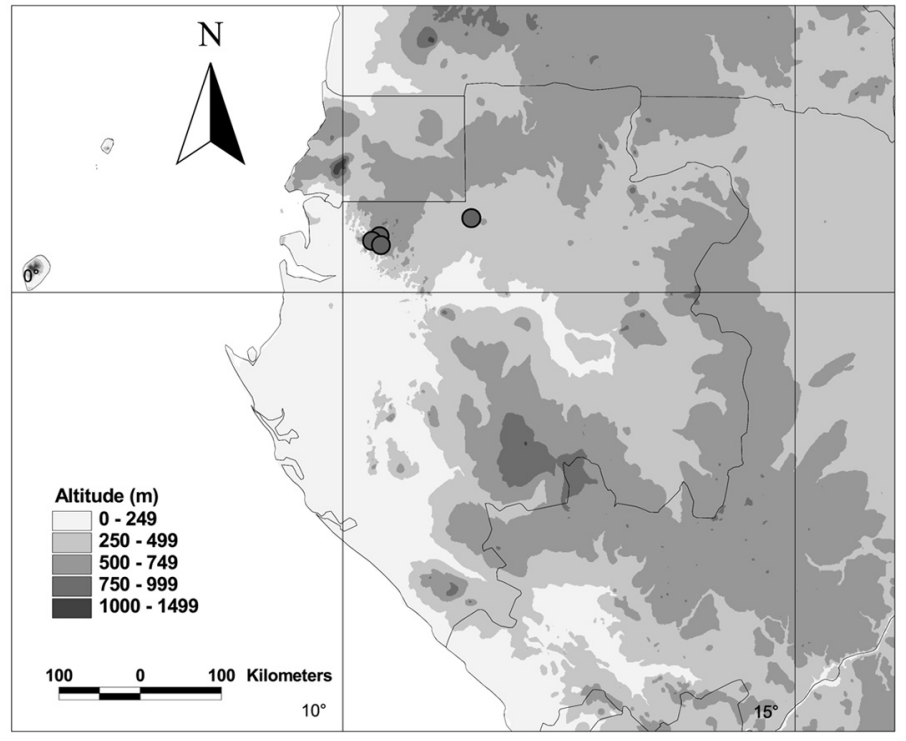

Map 1. Collecting localities of Campylospermum louisii Bissiengou \& Sosef in Gabon.

Additional material:

GABON: Louis, Breteler \& Bruijn 463 (WAG!), Woleu-Ntem, Lara River close to Etouk village on road Mitzic-Médouneu, 7 Nov. 1983; Wieringa 472 (LBV!, WAG!), Estuaire Province, $0.5 \mathrm{~km}$ southwest of Tchimbélé, 27 Jan. 1990, alt. \pm 520 m; Wilks AP 3445 (LBV!, MO, WAG!), Estuaire Province, $49030 \mathrm{~m}$ on transect G, Crystal Mountains, 3 May 2001.

The present work is part of a revision of Campylospermum started by the first author which, together with the research on African Ochnaceae by the second author (Sosef et al. 2007, Sosef 2008), should also lead to a treatment of the Ochnaceae for the Flore du Gabon.

While working on the genus Campylospermum with a special focus on Gabon, we came across two species names within the genus Ouratea Aubl., O. dusenii Engl. \& Gilg and O. leroyana (Tiegh.) Keay, obviously missed by Farron in his review of African Campylospermum species and their synonyms (Farron 1965, 1985). The latter two names also figure in the Checklist of vascular plants of Gabon (Sosef et al. 2006). According to Farron (1968, 1985), Sastre (1988) and Sosef (2008) Ouratea is now confined to South America, all Old World species belonging to either Campylospermum, Rhabdophyllum Tiegh. or Idertia Farron. Both O.dusenii and O. leroyana clearly belong to the genus Campylospermum. Sosef et al. (2007) already discussed the differences between $O$. dusenii and a closely related species, but refrained from making the necessary new combination because the status of $O$. dusenii was not clear then. We are now convinced that $O$. dusenii is a distinct species without any other synonyms, and hence the correct combination is proposed below. In contrast, we do have difficulties in trying to distinguish $O$. leroyana from highly similar species like $C$. strictum (Tiegh.) Farron and $C$. reticulatum (P.Beauv.) Farron. It may thus, after a full revision of the genus, well prove to be a synonym of an existing name in Campylospermum. For this reason we decided not to create a new combination for this second species yet. 


\section{Campylospermum dusenii (Engl. \& Gilg) Bissiengou \& Sosef, comb. nov.}

Ouratea dusenii Engl. \& Gilg in Engl. (1903) 260.

The holotype specimen, Dusén 289, seems to have been lost in B and no isotype has been located to date. It might therefore be necessary in the near future to designate a lectotype.

Distribution - Cameroun, Gabon and Equatorial Guinea.

\section{ACKNOWLEDGEMENTS}

The Moabi Foundation, the Missouri Botanical Garden and the National Herbarium of the Netherlands, Wageningen branch provided financial support which allowed the first author to perform this study. Roel Lemmens (ProtA, Wageningen) kindly translated the diagnosis into Latin. René Siep (WAG) made the high-quality scan of the type specimen. Finally, credits should also go to Janko van Beek, Theo Damen and Madelon Lohbeck, three students of Wageningen University who performed a preliminary study on the new species during an MSc course at the Biosystematics group and who provided a useful report.

\section{REFERENCES}

Bamps, P. \& C. Farron. 1967. Ochnaceae. Flore du Congo, du Rwanda et du Burundi. Jardin botanique national de Belgique, Bruxelles.

Breteler, F.J. 1990. Gabon's evergreen forest: the present status and its future. Mitt. Inst. Allg. Bot. Hamburg 23a: 219-224.

De Wilde, J.J.F.E. 1994. Cristal Mountains, Gabon. In: S.D. Davis, V.H. Heywood \& A.C. Hamilton (eds.), Centres of plant diversity. Vol. 1: Europe, Africa, South West Asia and the Middle East: 169-170. IUCN Publications Unit, Cambridge.

Engler, E. 1903. Ochnaceae africanae. Bot. Jahrb. Syst. 33: 231-275.

Farron, C. 1965. Les genres Rhabdophylum van Tiegh. et Campylospermum van Tiegh. (Ochnaceae) en Afrique tropicale (Note préliminaire). Bull. Jard. Bot. État 35: 389-405.

Farron, C. 1968. Contributions à la taxonomie des Ourateeae d'Afrique. Candollea 23: 177-228.

Farron, C. 1985. Les Ouratinae (Ochnaceae) d'Afrique continentale. Cartes de distribution et clés de détermination de tous les genres et espèces. Bot. Helv. 95: 59-72.

Hutchinson, J. \& J.M. Dalziel. 1954. Flora of West Tropical Africa, éd. 2, 1, 1. Crown Agents of Oversea Governments and Administration, London.

Sastre, C. 1988. Synopsis generis Ouratea Aublet (Ochnaceae). Bull. Mus. Hist. Nat. (Paris), 4e sér., sect. B, Adansonia 1: 47-67.

Sosef, M.S.M. 1994. Refuge begonias. Taxonomy, phylogeny and historical biogeography of Begonia sect. Loasibegonia and sect. Scutobegonia in relation to glacial rain forest refuges in Africa. Studies in Begoniaceae 5. Wageningen Agric. Univ. Papers 94-1: 1-306.

Sosef, M.S.M., D.J. Harris \& K.E. Armstrong. 2007. Novitates Gabonenses 64. A new species of Campylospermum (Ochnaceae) from coastal Gabon. Blumea 52: 15-19.

Sosef, M.S.M., J.J. Wieringa, C.C.H. Jongkind, G. Achoundong, Y. Azizet Issembé, D. Bedigian, R.G. van den Berg, F.J. Breteler, M. Cheek, J. Degreef, R.B. Faden, P. Goldblatt, L.J.G. van der Maesen, L. Ngok Banak, R. Niangadouma, T. Nzabi, B. Nziengui, Z.S. Rogers, T. Stévart, J.L.C.H. van Valkenburg, G. Walters \& J.J.F.E. de Wilde. 2006. Check-list des plantes vasculaires du Gabon / Checklist of Gabonese vascular plants. Scripta Bot. Belg. 35: 1-438.

Sosef, M.S.M. 2008. Révision du genre africain Rhabdophyllum Tiegh. (Ochnaceae), avec sa distribution au Cameroun et au Gabon. Adansonia, sér. 3, 30, 1: 119-135.

Wilks, C. 1990. La conservation des ecosystèmes forestiers du Gabon. IUCN, Gland. 